\title{
Articles
}

\section{The Industrial Arts Paradigm: Adjustment, Replacement, or Extinction?}

\author{
Steven C. Clark ${ }^{1}$ \\ Introduction
}

Industrial arts/technology education (IA/TE) is in a crisis - a crisis caused largely by the increasing changes that are occurring within society and technology. In the past five years, national, state, and local commissions, organizations, and educators have developed countless documents, curricula, and workshops on the subject of technology education (International Technology Education Association, 1985; Ferns, 1983, 1984, 1985, 1986, 1987, 1988; Hoopfer, Jost \& Nelson, 1987; Hales \& Snyder, 1981; Hull \& Smink, 1988; Kadamus \& Daggett, 1986; Maley, 1988; Michigan Department of Education, Vocational-Technical Education Service (MDE/V-TES), 1988, 1989; Savage, 1989; Virginia Vocational Curriculum Resource Center, 1988). Through various means, thousands of administrators, educators, and ancillary staff members have been exposed to technology education. IA/TE educators in Michigan strongly agree that technology should be a part of their programming, and, in some cases, identify technology education as what they currently teach (Smith, 1989). Still, the unit shop remains the primary delivery method in the field (Ellis, 1989; Smith, 1989). This serves to accentuate the scope of the crisis, and the professional reaction (or lack thereof) to it. It appears that many efforts in the movement toward technology education have failed because changes have been made in name only, rather than in instructors' understanding of the underlying philosophical differences between industrial arts and technology education. Because of the recurrence of name-change-only programs, and the fact that industrial arts teachers often do not perceive differences between industrial arts and technology education, it may be beneficial to the profession to view industrial arts as a paradigm.

In a 1985 position paper, Pratzner viewed vocational education as a paradigm while providing insightful views into the paradigm's configuration and possible metamorphosis to a new emerging paradigm of vocational education. Citing "significant technological changes, quality of work life developments, lagging productivity, quality and international competitiveness" (p. 6) as reasons for a possible paradigm shift, Pratzner presented a persuasive case for change. Key to Pratzner's paradigm development was an abstracted version of the six components Mohrman and Lawler (1981) believed to be essential to any paradigm: image of subject matter, beliefs in particular theories and models, values, methods and instruments, exemplars, and social matrices. Copa (1985) supported Pratzner's position that, in order to survive, vocational education must change to meet the needs of society and technology, and also used industrial arts as an example of an "old paradigm" (p. 28). Using Pratzner's conceptional framework and Copa's observation that industrial arts is surely an "old paradigm," the possibility of an "emerging paradigm" - technology education - is investigated in this paper.

An analogy may be drawn between Pratzner's view of the position of vocational education nationally and the state of IA/TE in Michigan schools. Ironically, Pratzner's perception of what vocational education should be ("developing, applying, and practicing basic skills and higher-order, transferable skills, judgements, and initiative [e.g., problem solving, decision making, planning] required of all learners") constitutes the philosophical base for what industrial arts education was designed to be (p. 9). It is also ironic that many IA/TE teachers see their programs as prevocational, if not vocational, in scope. This view impedes their coexistence with vocational educators and widens the already existing gap between general education courses and IA/TE laboratories and classrooms. The situation is unfortunate, because IA/TE belongs, both philosophically and historically, within the cluster of courses deemed necessary for the general education of all children.

1 Steven Clark is Assistant Professor, Center for Occupational Education, Ferris State University. 


\section{Paradigms in Crisis}

Thomas Kuhn (1962) coined the term "paradigm" to denote a universally accepted set of models and beliefs held by a "community of practitioners" (p. x). These models and beliefs govern and define the scope and mission of a paradigm. According to Kuhn, paradigm shifts occur when a paradigm enters a crisis-like state: "All crises begin with the blurring of a paradigm and the consequent loosening of the rules. . . and close with the emergence of a new candidate for paradigm and with the subsequent battle over its acceptance" (p. 84). Transition from one paradigm to a new one requires more than simply "an articulation or extension of the old paradigm" (p. 84). A reconstruction of the most elementary models and beliefs that guide members' behavior must occur; there will be translucent periods, during which problems can be solved by either set of beliefs, but "never complete overlap" (p. 84).

Industrial arts/technology education is a true paradigm in crisis, according to Kuhn's (1962) definition. Industrial arts teachers adhere to beliefs and traditions that are firmly established in successful pedagogical methodologies, which have served them well. That tradition may well be what has slowed the progress to a 21 st-century, technology-based paradigm. This new paradigm may be technology education for all students in public schools - a shift, in essence, from one set of beliefs to another.

According to Kuhn (1962), there should be a shift in methods and applications from the traditional to the new. If such a shift is achieved, "the profession will have changed its view of the field, its methods, and its goals" (Kuhn, 1962, p. 85). Thus, "the new paradigm is no longer seen as a radical approach, but as the only way to operate" (Mohrman \& Lawler, 1981, p. 21). The legitimacy of the traditional industrial arts paradigm is locked in the early 1900's. IA/TE teachers and students alike are prisoners in a content world that is so far removed from modern technology that many professionals in the field have difficulty simply justifying their existence to their general education colleagues.

In Pratzner's (1985) view, "A paradigm is a framework used by a community of adherents to explain and make sense of their world and to guide their efforts to further understand and improve it." (p. 7) IA/TE educators have rarely strayed beyond their conceptual framework, because as a group they understand it; improvements generally concern new ways to test old "technology." In the following sections, the six components abstracted by Pratzner (subject matter, beliefs, values, methods, exemplars, and social matrices) are used to distinguish between the paradigm of industrial arts and the hypothesized new technology education paradigm. A summary of these distinctions for each of the component areas is shown in Table 1.

\section{Subject Matter}

The industrial arts curriculum is industry based. However, the current curriculum reflects the technology of years past. In 1876, American educators marveled at the Russian system of manual training presented at the Philadelphia Centennial Exposition. The exhibit showed exercise pieces of both wood and metal; students learned segments of a process through exercise and practice (Bennett, 1937). However, the working blueprints for student projects shown in Bennett's History of Manual and Industrial Education, 1870 to 1917, could have come from almost any modern industrial arts program.

The curriculum of the industrial arts paradigm is based on definitions that depict the subject matter. Bonser and Mossman (1924) defined industrial arts as a study of the changes people make in the forms of materials to increase their value and of the problems of life related to those changes. Bennett (1937) stated that industrial arts is essentially the same as manual arts (forerunner of industrial arts), although its connotations are different. In industrial arts, the "industrial" is emphasized, whereas in manual training (forerunner to manual arts), "manual" is stressed.

Bonser (1930) thought the term "field" was more fitting than the word "subject" because industrial arts represented a number of subjects. This was one of the first references to "subjects" in the literature on industrial arts; the move was being made from the general shop to the "unit shop."

During the next 40 years, people like Warner (1947), Olson (1955, 1963, 1972), Hales \& Snyder, (1981), and Maley $(1975,1978)$, returned to the broad study of the materials, organizations, tools, processes, products, jobs, and human problems of industry as their content statement for the profession. Four years ago, Bensen (1985), Ferns \& Clark (1985), and Rudnick (1985) urged industrial arts teachers to re-evaluate their course content because of what they saw as an outdated curriculum based on "industry."

Over the past 70 years, the subject matter in industrial arts classrooms and laboratories has undergone little change. The philosophy of teaching the tools, processes, and materials of industry has served the existing paradigm well. However, if the emerging paradigm is to become dominant in the area of subject matter, the content of technology education courses will have to evolve rapidly. 
Table 1

Current and Emerging Paradigms of Industrial Arts

\begin{tabular}{|c|c|c|}
\hline $\begin{array}{l}\text { Components of } \\
\text { a Paradigm }\end{array}$ & Industrial Arts & Technology Education \\
\hline Subject Matter & $\begin{array}{l}\text { Material shops } \\
\text { Avocational skill } \\
\text { Serves the interests of } \\
\text { local instructors }\end{array}$ & $\begin{array}{l}\text { Human-adaptive systems: } \\
\text { manufacturing, transportation, } \\
\text { communication, construction } \\
\text { Developmental skills for all } \\
\text { students } \\
\text { Experimental approach to } \\
\text { concepts/content } \\
\text { Integrated knowledge }\end{array}$ \\
\hline $\begin{array}{l}\text { Theories and } \\
\text { Models }\end{array}$ & $\begin{array}{l}\text { Late } 19 \text { th century/early } \\
\text { 20th century industry } \\
\text { Teachers impart knowledge } \\
\text { Product emphasized } \\
\text { Step-by-step methods } \\
\text { Drill and practice }\end{array}$ & $\begin{array}{l}\text { Problem solving } \\
\text { Critical thinking } \\
\text { Process emphasized } \\
\text { Supports total curriculum } \\
\text { Trial and error }\end{array}$ \\
\hline Values & $\begin{array}{l}\text { Individualized instruction } \\
\text { Survival skills } \\
\text { Leisure-time skills } \\
\text { Hands-on } \\
\text { Alternate track for academically } \\
\text { less able, less willing }\end{array}$ & $\begin{array}{l}\text { Individualized instruction } \\
\text { and performance } \\
\text { Cooperative learning } \\
\text { Action based/hands-on } \\
\text { Applications of technology }\end{array}$ \\
\hline $\begin{array}{l}\text { Methods and } \\
\text { Instruments }\end{array}$ & $\begin{array}{l}\text { Domain-referenced testing } \\
\text { Psychomotor skill development } \\
\text { Individual predesigned projects }\end{array}$ & $\begin{array}{l}\text { Group problem solving } \\
\text { Individual problem solving } \\
\text { Generalizable skills } \\
\text { Total domain learning: } \\
\text { cognitive, affective, } \\
\text { psychomotor } \\
\text { Scientific inquiry }\end{array}$ \\
\hline Exemplars & $\begin{array}{l}\text { Unit shops } \\
\text { Locally developed programs } \\
\text { Vocational or prevocational } \\
\text { education } \\
\text { Survival skills }\end{array}$ & $\begin{array}{l}\text { Today's technology } \\
\text { Transferable knowledge } \\
\text { Unified mission }\end{array}$ \\
\hline Social Matrices & $\begin{array}{l}\text { AIAA, state and local } \\
\text { divisions } \\
\text { Armchair curriculum development } \\
\text { School Shop } \\
\text { Project fairs }\end{array}$ & $\begin{array}{l}\text { ITEA, state and local } \\
\text { divisions } \\
\text { The Technology Teacher } \\
\text { ITEA: Stanley/Proto mass- } \\
\text { production competition } \\
\text { Advisory committees } \\
\text { Technology-based student } \\
\text { organizations } \\
\text { Science/technology fairs } \\
\text { ITEA: technology fairs }\end{array}$ \\
\hline
\end{tabular}

NOTE: The designation of the six components of a paradigm was abstracted from

Lawler (1981). Some signifiers were developed by Pratzner (1985).

Many IA/TE programs in Michigan exist today because of a strong traditional commitment to an instructor or a special population within the school district served by those programs (Rudnick, 1985). The emerging paradigm of technology education, which is the alternative to industrial arts education, eliminates the dedication to special-interest groups and moves back into the general education curriculum with a program designed to serve the needs of all students - a general education course dealing with an understanding of today's technological society.

The new paradigm of technology education is based in the 21st century and beyond. Four humanadaptive systems of subject matter embody four major areas of contemporary society. Communication technology involves efficiently using resources to transfer information to extend human potential. Construction technology involves efficiently using resources to build structures or constructed works on a site. Manufacturing technology involves efficiently using resources to extract and convert raw/recycled materials into industrial and consumer goods at a central plant location. Transportation technology involves 
efficiently using resources to obtain time-and-place utility and to attain and maintain direct physical contact and exchange among individuals and societal units through the movement of materials/goods and people (ITEA, 1985).

Savage (1989) took the evolution of technology education one step further to expand the subject matter base. State departments of education in Michigan, New York, and Ohio are currently considering this "systems" approach (Smith, 1989), which consists of bio-related, physical, and communication technologies. Bio-related technology subject matter ranges from societal concerns regarding waste treatment to technological issues related to agriculture. Physical technology subject matter ranges from societal concerns for alternate energy sources to the technological problems confronting manufacturing engineers. Communication technology subject matter ranges from computer-aided drafting (CAD) to laser communication systems (Savage, 1989).

The content areas of the new paradigm can be based in society as well as industry and will not create specialists in any field within either realm. Understanding the social implications of work and change and developing problem-solving and critical-thinking skills are but a few of the major goals of the technology education paradigm. Justifying one's existence within general education through the integration of all subject areas becomes a matter of one's technological focus.

\section{Theories and Models}

Paradigms encompass a number of characteristic theories and models that explain and relate the variables defining subject matter (Mohrman \& Lawler, 1981). The paradigm of industrial arts is based on the labor-intensive model of industry that existed at the time of the industrial revolution in America. Content is determined from a trade and job analysis of selected occupations such as cabinetmaking, drafting, printing, welding, and so on.

Even though early federal funding of vocational education programs (Smith-Hughes Act of 1917) removed trade-specific training from the general education mainstream, a need remained to develop a philosophical base on which the two disciplines could grow. Technology analysis (Warner, 1947), human needs analysis (Maley, 1976), the Industrial Arts Curriculum Project (Lux \& Ray, 1971), and socialcultural analysis (DeVore, 1965), were all attempts to establish a philosophical base for industrial arts education. However, the difference between industrial arts and vocational education was never clearly defined and implemented as a universal practice. The unit shops of the existing paradigm survived as generic reflections of industry; most of them still model specific job training.

Dewey's "project method" $(1933,1942)$ of scientific problem solving was well suited for industrial arts, with its emphasis on tools and equipment. Industrial arts teachers could pose hypothetical problems, and students could work until they found acceptable solutions. In theory, this approach was to be the embodiment of all educational efforts toward problem solving. For many years industrial arts prided itself as one of the prime forces in the development of problem-solving techniques (Ferns, 1962; Lux \& Ray, 1971; Maley, 1985; Olson, 1972). However, (in most industrial arts shops) the movement from student irritation with a problem that needed a solution to an examination of actual conditions never crystallized. The problems posed by industrial arts teachers primarily involved machine operation and tool manipulation. The industrial arts paradigm seldom articulated the full intent of Dewey's concern to break down the dichotomy between means and ends (Archambault, 1964). The tools and machinery served as the means to produce a functional product (project) that was an end in itself.

The mechanistic content of the industrial arts paradigm is arousing divergent thinking among practitioners. The models and theoretical genesis of the technology education paradigm are derived from the ways human beings adapt to contemporary technological society (Savage, 1989). The technology education curriculum is in a constant state of flux. The major concerns lie with problem-solving and criticalthinking skills, futuristic thinking, adaptability, and application of general skills for a productive life (ITEA, 1985). These broad areas can be covered in the total school curriculum because technology is the thread that runs through all subjects and affects all people. The "key to success" is to apply technology to develop an understanding of the processes American society must encounter and overcome while staying competitive in a world economy (Naisbitt, 1984). The global concept, applied as an integrated curriculum within the school building, will guide educators in the 21 st century. That integration of curriculum stands at the core of technology education for all students (Maley, 1985).

\section{Values}

A democratic society provides equal educational opportunity of the same quantity and quality (Dewey, 1942). Many of the values currently held by industrial arts supporters run contrary to this expectation. Instructors in the industrial arts paradigm link directly with the values of industry: drill and practice, assembly lines, scientific management, and no-work-equals-no-pay evaluation models. Many educators describe industrial arts courses in general as "good for those kids." This shields them from 
critics who seek to evaluate their program content in the light of current educational reforms and technological advances. The valued curriculum becomes a continuum from developmental shop work to advanced shop work. The only curriculum that can exist in this environment depends on the two major factors that have always driven vocational education: (a) task analysis based on terminal objectives (Finch \& Crunkilton, 1979) and (b) the material (wood/metal, etc.) primary to the course (Rudnick, 1985). Placement of students in jobs related to their course work becomes a strong program goal. This progression from basic shop work to vocational work was criticized as early as 1923 (Bonser et al., 1923) and has continued to reduced the general education value of the IA/TE curriculum.

The curriculum in the emerging technology education paradigm bases its values on solid educational goals. "Successful education," as seen by Goodlad (1978), Dewey (1942), and others, focuses on problem solving, sensitive human relations, self-understanding, and the intergration of one's total experience into an educational system that aims toward self-renewal and lifelong learning. Just as the word "technology" conjures images of change and the future, the emerging technology education paradigm seeks to advance beyond the philosophy of industry as content. With technology as the charge, class content will change as industry and society change.

Using the total school curriculum as a resource base, the new technology education paradigm lends credence to its philosophical position within general education. The role of technology in the 21st century has as many social implications (Adler, 1982) as it does industrial ones. Change is the key. All educational curriculum springs from some image of the future. If the image of the future held by a society is grossly inaccurate, its education curriculum will betray its youth (Toffler, 1974). Technology education will instill in students the developmental skills they will need, regardless of their vocational aspirations.

\section{Methods and Instruments}

The unit shop within junior and senior high schools is the most unifying feature of the industrial arts paradigm. The tools and equipment common to hand and machine working of a specific material can be found in these unit shops. Wood shops, metal shops, and drafting rooms all represent common unit shops that have existed since the late 1800's. In 1876, Runkle (cited in Barlow, 1967) expressed the need to (a) separate instruction shops from construction shops, (b) provide only one kind of work in each shop, (c) provide as many work stations and tools per student as can be handled in one instructional period, and (d) graduate the instruction in each shop according to the difficulty of the operation. This moved general shop instruction into the specialization that the United States needed as it progressed from an agrarian society through the first industrial revolution. Many industrial arts educators thus adopted Runkle's and others' concept of the unit shop. Today, approximately $95 \%$ of the IA/TE programs in Michigan still deliver programs by means of the unit shop (Ellis, 1989; Smith, 1989).

The methods of instruction and evaluation in the old industrial arts paradigm tend to be psychomotor skill development and domain-referenced testing. The skills inherent in the material with which students work dictate the range in the domain for which testing is done. The hands-on techniques for developing psychomotor skills are generic to both the existing and the emerging paradigms. The philosophy and mission behind the processes in the alternate paradigm of technology education make it vastly different from the existing paradigm.

Major program goals involve generalization of problem-solving and critical-thinking skills. The models developed by students in the emerging paradigm involve skill development in all domains of learning: cognitive, affective, and psychomotor. These skills are fostered through both group and individual-learning activities in the technology education classroom and laboratory.

Characteristics of the emerging paradigm of technology education are consistent with the "effective schools" research (Brookover \& Lezotte, 1979; Edmonds, 1978), in that high expectations exist for all students. Because technology education is based on society in the 21st century, with communication, construction, manufacturing, and transportation systems forming the core curriculum, each student has the opportunity to excel in many areas. The rationale for including technology education in the general education curriculum need not be the largely unproven hypothesis that the existing paradigm retains potential high school dropouts or that "those kids" cannot succeed anywhere else. Technology education is relevant for all students, regardless of their academic goals.

\section{Exemplars}

When Kuhn (1962) defined the term "paradigm" in the late 1950's, he identified it as a group of "universally recognized scientific achievements" (p. x). These "achievements" make up the rules-andregulations to which paradigm practitioners adhere. Mohrman and Lawler (1981) exchanged the concept of "scientific achievements" for "exemplars." They stated that exemplars are absolute necessities in the existence of a paradigm because its very existence depends on specific identifiable traits common to the paradigm. The exemplars of industrial arts are the existence and perpetuation of the unit shop and in- 
consistency in the curriculum (Rudnick, 1987). Locally developed courses such as "crafts," "home maintenance," and others too numerous to list , all of which are delivered under the name of industrial arts, display a decisive lack of mission. The only common exemplars seem to be survival skills for the handyman and introductory-level courses that advance shop-work skills generic to a specific vocational course. Pratzner (1985) claimed that the industrial arts paradigm is an alternative to the existing paradigm of vocational education. This observation is true of the emerging technology education paradigm; however, the exemplars that describe the current industrial arts paradigm are inconsistent and have difficulty linking to any curriculum.

Exemplars of the alternative paradigm can be found in the engineering departments of business or industry, with people working together on a collective charge in which each participant is responsible for his or her own area of expertise, while understanding conceptually the contribution each member is making. Manufacturing Engineering recently published its "Ten Top Places to Work" (Hayner, Redebaugh, Stauffer, Bergstrom, \& Owen, 1989); the exemplar common to these companies was "teamwork" or "team." The alternate paradigm of technology education encourages teamwork while using knowledge and processes that are common to today's society and technology. Students individually develop strategies to accept the inevitable changes taking place outside the classroom. This teaching attitude gives students responsibility for their own education.

\section{Social Matrices}

Paradigms cannot exist without the support of a group of adherents (Kuhn, 1962) or a social network that adopts the ideas and practices of the profession (Mohrman \& Lawler, 1981). Articulation of ideas through both social and professional networks strengthens and supports the exemplars of a paradigm, both internally (among the members) and externally (outside the present membership). Since the late 1800's, the existing paradigm of industrial arts has gained numerous supporters from both industry and education. The American Industrial Arts Association was the professional organization that represented the paradigm of industrial arts. The AIAA held national and regional conferences, seeking to solidify and support teachers of the many industrial arts content areas. The other national network for the industrial arts profession was the Industrial Arts Division of the American Vocational Association. Many states have within their departments of education a similarly named unit with responsibility for industrial arts. State organizations also provide leadership with conferences and student project fairs. The Technology Student Association (formerly the American Industrial Arts Student Association) has student members from every state and gives students opportunities to expand their horizons within the existing curriculum.

The social matrices that support the new technology education paradigm are emerging and becoming more predominant. The AIAA renamed itself the International Technology Education Association (ITEA) in February 1985. In 1988, the Industrial Arts Division of the AVA proposed changing their name to the Technology Education Division. Many state organizations have changed to a technology-based paradigm, some by slim margins during member voting. Kuhn (1962) wrote that the "emergence of a new candidate for paradigm" is followed by "the subsequent battle over its acceptance" (p. 84). The ITEA changed its "official" magazine title to The Technology Teacher, in affirmation of the emerging paradigm, whereas others like School Shop resist changing their names, in order to serve both paradigms.

The social and political pressure to produce technologically literate youth has seldom been more publicized than in the past five years. The discussion of the Technology Education Act in 1985 by Congress and House of Representatives began the trend of national support for the new paradigm. Today, there are strong indications that future amendment(s) of the Perkins Act will favor technology education (Smith, 1989). This progression portends strong social promise for the technology education paradigm. Adler's (1982) Paideia Proposal called for the type of holistic education embodying the emerging paradigm of technology education.

The strength of the social matrices and methods used to support and deliver the new paradigm shows that professional attitudes are changing. There is little question as to the existence of the old industrial arts paradigm based on the aforementioned components. However, the social matrices are in place for a shift, if the methodology is developed, articulated, and followed up. This transition requires a solid philosophical understanding. The new paradigm must, at some point, make sense to industrial arts proponents.

\section{Anomalies and Crises}

Major anomalies within the existing paradigm of industrial arts have caused crises that have translated into noted reductions in the professional staff serving the paradigm (Ellis, 1989; Rudnick, 1985; Smith, 1989). This reduction raises concern among adherents of both the dominant and emerging paradigms, for one must have something from which to "emerge." The anomalies and crises necessary to provoke a paradigm shift must be great enough to disturb the adherents (Kuhn, 1962). Almost 60 
percent of Michigan's IA/TE teachers believe their programs need to change, which appears to indicate crisis for the existing paradigm. Fewer and fewer school districts are finding the values and philosophy of the industrial arts paradigm result in viable programming. Many IA/TE teachers have been relegated to part-time status; while the tools and equipment used in their programs are being sold, and the numbers of courses offered are dropping at an alarming rate. In Michigan, the average IA/TE instructor is 44 years old and has 17 years of experience, with more than 10 years of service remaining (Smith, 1989). If the emerging paradigm of technology education is to be delivered by the present instructors, change must occur rapidly. The existing trend points to the extinction of industrial arts and the elimination of a universally accepted technology education paradigm.

\section{Conclusions}

A paradigm shift depends on many variables. The theories of Kuhn (1962), with abstractions by Mohrman and Lawler (1981), and Pratzner (1985), provide an excellent framework for understanding the components of a paradigm. The examples referred to in this paper revealed that a shift in the industrial arts paradigm is feasible. The strength of traditional industrial arts ideologies accounts for its longevity. However, the tools and machinery of the field disguise these ideologies, and a majority of students do not elect to become involved in the existing programs.

The emerging paradigm seeks to develop the three noted domains of learning: affective, cognitive, and psychomotor. This gives technology education a distinct advantage over the present paradigm, which in many cases has never lived up to its purported problem-solving capabilities (Ferns, 1962). A curriculum that addresses the needs of a technological society has never been in more demand. A recent survey indicated that less than half $(43.7 \%)$ of the IA/TE teachers in Michigan considered themselves knowledgeable on the subject of technology education (Smith, 1989). Technology education must evolve rapidly, if adherents of the current paradigm are expected to be a part of the new paradigm.

It would be presumptuous to assume that the alternate paradigm of technology education is a "fad" rather than a trend in educational reform. The framework for a paradigm shift has been established in New York, Wisconsin, Illinois, Ohio, Virginia, Michigan, and California, and other states are developing support for such a shift. The Industrial Arts Curriculum Project (IACP) at The Ohio State University (Lux and Ray, 1971) fell short of national acceptance, largely due to timing. Lux \& Ray's work in manufacturing and construction has become an integral component of the core curriculum of the emerging paradigm. The career education movement of the mid-1970's lost momentum and all but died because of infighting about who could deliver the service within existing curricula. The movement failed because of an internal articulation problem (Pratzner, 1985), not because the crisis career education set out to alleviate was not real.

The alternate paradigm of technology education has developed strong support at most levels of American society. That support has come through a strong push by technology education supporters to change the "attitude" of many toward technological instruction in the public schools (Bensen, 1985). The price of teaching technology within the new paradigm is a bargain when compared to that of instructing students within the existing paradigm. Ignoring the potential of the alternate paradigm and failing to articulate a well-defined model may endanger both the existing and the alternate paradigms.

\section{References}

Adler, M. (1982). The paideia proposal. New York: Macmillan.

Archambault, R. (1964). John Dewey on education: Selected writings. New York: Random House.

Barlow, M. (1967). History of industrial arts in the United States. Peoria, IL: Charles A. Bennett.

Bennett, C. (1937). Bennett unveils fantasy high school curriculum. Report on Education Research, Alexandria, VA: Capitol Publications.

Bensen, J. (1985, January). The soaring technology revolution. The Technology Teacher, 4.

Bonser, F. G. (1930). Industrial arts for the public school. New York: Intext Education Press.

Bonser, F., \& Mossman, L. (1924) Industrial arts for elementary schools. New York: Intext Educational Press.

Brookover, W., \& Lezotte, L. (1979). Changes in school characteristics coincident with changes in school achievement. East Lansing: Michigan State Universtiy, College of Urban Development.

Copa, P. (1985). Reaction to Pratzner. Journal of Industrial Teacher Education, 22(2), 28.

DeVore, P. W. (1980). Technology, an introduction. Worcester, MA: Davis Publications.

Dewey, J. (1933). How we think. Boston: D. C. Heath \& Company.

Dewey, J. (1942). The school and society. Chicago: University of Chicago Press. 
Edmonds, R. (1978, July). A discussion of the literature and issues related to effective schooling. Paper presented at the National Conference on Urban Education, St. Louis, MO.

Ellis, A. (1989). An identification of the incentives that motivate Michigan industrial arts teachers to participate in professional-growth activities. Unpublished doctoral dissertation, Michigan State University.

Ferns, G. (1962). Principles for designing and conducting learning experiences for improving problemsolving abilities as applied to industrial arts teachers. Unpublished manuscript, Michigan State University, East Lansing.

Ferns, G. (1983-1988). Final reports, industrial arts needs assessment and workshop summaries: The vocational education personnel development project (Michigan Department of Education, Vocational/Technical Education Service). East Lansing: Michigan State University.

Ferns, G., \& Clark, S. (1985). Summative evaluation--future directions for industrial arts workshops: Vocational education personnel development project (Michigan Department of Education, Vocational/Technical Education Service). East Lansing: Michigan State University.

Finch, C., \& Crunkilton, J. (1979). Curriculum development in vocational and technical education. Boston: Allyn \& Bacon.

Goodlad, J. (1978). What schools are for. Bloomington, IN: Phi Delta Kappa Education Foundation.

Hales, J., \& Snyder, J. (1981). Jackson's Mill industrial arts curriculum theory. Charleston: West Virginia Department of Education.

Hayner, A., Redebaugh, J., Stauffer, R., Bergstorm, R., \& Owen, J. (1989, July). Ten top places to work. Manufacturing Engineering, 103, 37-49.

Hoopfer, L., Jost, D. \& Nelson, C. (1987). Spaces: Preparing kids for high tech and global future. East Lansing: Michigan 4-H Foundation.

Hull, W., \& Smink, J. (1988). WE-2: Washtenaw education for employment . . working for tomorrow. Columbus: National Center for Research in Vocational Education, The Ohio State University.

International Technology Education Association. (1985). Technology education: A perspective on implementaion. Reston, VA: ITEA.

Kadamus, J., \& Daggett, W. (1986). New directions for vocational education at the secondary level. Albany: New York State Educational Department.

Kuhn, T. (1962). The structure of scientific revolutions. Chicago: University of Chicago Press.

Lux, D., \& Ray, W. (1971). Industrial arts curriculum project (The Ohio State University Research Foundation). Bloomington, IL: McKnight \& McKnight Publishing.

Maley, D. (1975). Cluster concept in vocational education. Chicago: American Technical Society.

Maley, D. (1978). The industrial arts technical handbook: Techniques, principles, and methods. Boston: Allyn \& Bacon.

Maley, D. (1985). Math, science, technology projects: A professional monograph. Reston, VA: International Technology Education Association.

Maley, D. (1988). Technology resource package. Reston, VA: International Technology Education Association.

Markert, L. (1989). Contemporary technology: Innovations, issues, and perspectives. South Holland, IL: Goodheart-Wilcox.

Michigan Department of Eduation, Vocational/Technical Education Service. (1988). Technology education: Public information handbook. Lansing: Author.

Mohrman, A., \& Lawler, E. (1981). The diffusion of OWL as a paradigm shift. Los Angeles: Center for Effective Organizations, Graduate School of Business Administration, University of Southern California.

Naisbitt, J. (1984). Megatrends. New York: Warner Books.

Olson, D. (1955). Industrial arts for the general shop. New York: Prentice-Hall.

Olson, D. (1963). Industrial arts and technology. Englewood Cliffs, NJ: Prentice-Hall.

Olson, D. (1972). The new industrial arts: A guiding definition (5th ed.). Raleigh: North Carolina State University.

Pratzner, F. (1985). The vocational education paradigm: Adjustment, replacement or extinction? Journal of Industrial Teacher Education, 22(2), 6.

Rudnick, J. (1985, Fall). The future of industrial arts in Michigan. Michigan Industrial Arts Society Journal.

Rudnick, J. (1985). Personal communication with the author.

Savage, E. (1989). A model for technology education in Ohio. Bowling Green, OH: The Model Technology Systems Project.

Smith, J. (1989). Technology education/industrial arts status survey. Lansing: Michigan Department of Education, Vocational/Technical Education Service. 
Toffler, A. (1974). The psychology of the future. Learning for tomorrow: The role of the future in education. New York: Vintage Books.

Virginia Vocational Curriculum and Resource Center. (1988). The technology education curriculum $K-12$. Richmond: Virginia Department of Education.

Vocational Education Act of 1917.

Vocational Education Act of 1984.

Warner, W. (1947). Policies in industrial arts education. Englewood Cliffs, NJ: Prentice-Hall. 